\title{
The Belarusian Orthodox Church and Its Role in the Belarusian Regime
}

Acta Fakulty filozofické Západočeské univerzity v Plzni / West Bohemian Review of Social Sciences \& Humanities 2021, Vol. 13 (2), 1-15 DOI: https://doi.org/10.24132/actaff.2021.13.2.1 https://actaff.zcu.cz/ ISSN 2336-6346

\author{
Maria Avanesova* \\ University of West Bohemia, Czech Republic
}

\begin{abstract}
This text, conceived as an interpretative case study, deals with the role that the Belarusian Orthodox Church plays in the contemporary Belarusian regime. In light of the fact that the Belarusian Orthodox Church is an exarchate of the Russian Orthodox Church, the author will also look at whether the Belarusian Orthodox Church can actually be considered an instrument of Russian in Belarus. Within the research, the author will show that on the one hand, there are favorable conditions for the development of the Belarusian Orthodox Church. But on the other hand, although the state declares the de facto independence of the Belarusian Orthodox Church, any opposition activity on its part is seen as a threat to the state, which allows the state to interfere with its policy. This leads church organizations in such systems to become significantly weakened within this "cooperation with the state", even though they have an influence on society and thus a legitimizing potential. As a result, the church is strongly dependent on the state and limited as an actor in civil society within the Belarusian regime. In addition, the author will also conclude in the study that it is difficult to consider the Belarusian Orthodox Church to be a tool of the Kremlin's influence.
\end{abstract}

\section{Keywords}

Belarus, Belarusian Orthodox Church, Lukashenko, Russia, Russian Orthodox Church

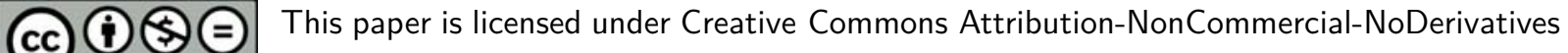
4.0 International License.

\section{Introduction}

The relationship between the state (or more precisely the political sphere) and the church is a frequent subject of political-scientific analyses. There is a whole score of topics that political science (or more generally social science) studies in the context of this issue, be it questions of secularization (e.g. Åberg, Denk 2017; Wilkins-Laflamme 2016), the existence of political parties linked to a religious or church principle (e.g. McGraw 2014; Schwörer, Romero-Vidal 2020), the role of churches in domestic and foreign policy (e.g. Avanesova, Naxera 2018; McCallum 2012), the role of churches or their leaders in conflicts (e.g. Letsie 2015; Serapião 2004) and their participation in international organizations activities and international relations (e.g. Leustean 2018; Sekerák 2014), and many others. The role of the church in the context of a non-democratic regime is a

\footnotetext{
* Corresponding Author: Maria Avanesova, Department of Politics and International Relations, Faculty of Arts, University of West Bohemia, Jungmannova 1, 30100 Pilsen. E-mail: mariavanesov@gmail.com.
} 
highly interesting issue. In general, the debate on the church as an institution in an undemocratic regime is an important one in terms of the research of undemocratic regimes. As of late, increasing attention has been paid to this issue. This is happening primarily because one of the key strategies in the legitimization of undemocratic regimes is their cooperation with various institutions that have an influence on society.

In scientific literature, the three following models of relations between undemocratic regimes and churches are mentioned the most frequently (e.g. Koesel 2017: 677-679). The first is a model in which churches and their representatives conflict with the existing regime by casting doubt on its legitimacy. The most commonly cited example of this model of relations is the relationship between the Catholic Church and communist regime in Poland, as the Catholic Church in Poland strongly contributed to the delegitimization of the communist regime and played an important role in its fall (Philpott 2004, 2007). The second model of relations is one in which authoritarian leaders can persecute religious organizations by significantly interfering in their operation and attempting to gain total control over their activity. Religious organizations can put up only weak resistance to this, which only leads to greater persecution. As a result, religious organizations and their activity fall completely under state control (Koesel 2017: 677-679). An example of this is the relationship between the church and state in Russia throughout the majority of the USSR's existence. The third model is a model of cooperation in which the state plays a leading role. Religious institutions and church representatives legitimize the activity of the state. In light of the fact that a religious organization is not an enemy in this case, the state can grant it opportunities that are denied to other religious groups and institutions, such as financial advantages or access to the education system and mass media (Koesel 2017: 677-679).

In my opinion, the Belarusian Orthodox Church (hereafter BOC), which is dealt with in this text, does not belong to any of these groups and is another example of the possible existence of churches in a non-democratic regime. It should primarily be mentioned that the Belarusian Orthodox Church is the exarchate of the Russian Orthodox Church (hereafter ROC), which means that its powers are limited. ${ }^{1}$ However, despite its subordination to ROC, BOC is very popular in Belarus. According to public opinion polls, $70-80 \%$ of Belarus's population are Orthodox believers, although only a small portion of this group regularly visits churches or takes part in church rituals (Vasilevich 2013: 83; Urban 2019: 51-54). It is improbable that the majority of the population of Belarus sees the activity of religious actors as an appeal to their own political and social engagement; however, this does not fundamentally disrupt the respect and trust of statements made by these Orthodox actors and the acknowledgment of their authority in the field of both morality and politics. This means that the church has a significant legitimization potential (e.g. Avanesova, Naxera 2018), which could be advantageous for an undemocratic regime like today's Belarus.

This text, which is conceived as an interpretative case study, deals with the role that the Belarusian Orthodox Church plays in the contemporary Belarusian regime. In light of the fact that the Belarusian Orthodox Church is an exarchate of the Russian Orthodox Church, the author also will take a look in this text at whether the Belarusian Orthodox Church can actually be considered a Russian tool of influence in Belarus.

\footnotetext{
1"The exarchate (of which their is only one within ROC - the Belarusian exarchate) unites eparchies in one independent state, where the Orthodox religion is the faith of the religious majority. Therefore, it also has the right to be called the "Belarusian Orthodox Church" and its head has the additional title of "Patriarchal Exarch". The synod primarily carries out coordinating functions, all bishops including the head are nominated in Moscow, and all decisions of the synod become valid after approval by the patriarch" (Shramko 2014).
} 


\section{The Belarusian exarchate and the Belarusian state after the dissolution of the USSR}

According to Russian patriarch Alexy II, "preserving the unity" of the Russian Orthodox Church was one of the priorities of his activity. After the dissolution of the USSR, this was possible only in the case of preserving the unity of the eparchy and the parish on the canonical territory of ROC, which includes the whole post-Soviet space (with the exception of Armenia and Georgia), Mongolia, Japan and China. Fears of the processes that took place on the eve of the collapse of the USSR forced the ROC's Holy Synod to accept the church formula of "several states - one patriarchate", meaning that the borders of the patriarchate do not necessarily have to coincide with state borders, as the patriarchate is not a political, national or geographical term (Lomagin 2012: 503; Bezborodov 2010: 84; Ryabych 2004: 143). Such a formula also explained that the collapse of the secular federation cannot be a sufficient reason for disrupting the unity of the church (Curanović 2012: 133).

However, as early as 1990, church leadership was faced with problems in West Ukraine, where the battle against ROC was supported by local leaders. ROC's leadership feared repeating a similar situation in Belarus, and therefore provided the Belarusian and Ukrainian Orthodox Churches with autonomy before the dissolution of the USSR. In Belarus's case, this autonomy was more limited than in the case of Ukraine. Such a decision made it possible to sacrifice a part of ROC's competencies but preserve its operation in the region. However, ethnic nationalism continued to represent the greatest threat to the operation of ROC in countries that would have remained outside Russia after the dissolution of the USSR, and therefore the Estonian, Latvian and Moldavian Orthodox Churches gained partial autonomy in December of 1991 (Mitrofanova 2007).

The steps taken allowed ROC to preserve its influence and the cultural and spiritual unity of the former Soviet Union (Bezborodov 2010: 84). However, the ROC was not powerful enough to stop political disintegration processes in all places where the majority of the population professed the Orthodox religion (Mitrofanova 2007). The political elites of Ukraine, Estonia and a part of the Belarusian opposition openly feared that the church was a structure that would be willing to support the imperialist activity of Russian political powers in post-Soviet space (Bezborodov 2010: 85), and therefore continued to strive for complete independence from ROC and the creation of their own church or for the subordination of the local Orthodox community to another patriarchate (Bezborodov 2010: 84). If their efforts were actively supported by the ruling elites, other Orthodox (and even schismatic) churches (Estonia, Ukraine) appeared, which were perceived as national churches and were capable of competing with ROC (Mitrofanova 2007). In the case of the absence of such support, as for example in Belarus, separatist processes brought few results, even though the Belarusian Autocephalous Orthodox Church. Its activity was not allowed on the territory of Belarus even after the dissolution of the USSR.

The creation of the Belarusian exarchate (alternate name - Belarusian Orthodox Church) was also linked to the renewal of old eparchies and the founding of new ones on the territory of Belarus. Preservation of the influence of ROC in Belarus was due not only to the provision of partial autonomy to the Belarusian Orthodox Church or the traditionally good ties between the Russian and Belarusian nations, but also the support that the church provided Lukashenko during the presidential elections in 1994 (Budkin 2007: 31). This was a logical decision for the church. Although they knew that Lukashenko was an atheist, they were also aware of the fact that he was an Orthodox atheist (Vojtovich 2003). This means that, contrary to his opponents, he did not express interest in close cooperation with the West and strengthening the influence of Catholicism and uniatism on Belarusian society. For the church, which was striving to preserve unity on its canonical territory and spoke of the need to unite within the Slavic "Russia-UkraineBelarus" triangle after the dissolution of the USSR (Ryabych 2004: 144), similar opinions of the opposition were unacceptable. 
The position of the Belarusian exarchate as an actor in Lukashenko's regime transformed based upon how Lukashenko's regime was solidified. Lukashenko evidently realized rather quickly that BOC could be used as a tool of legitimization. At first glance, it may have seemed that BOC had a certain freedom in the system; however, in reality, the relationship between Belarusian leadership and the church could not and cannot today be considered equal cooperation (Vasilevich 2015: 114-115), even despite the fact that Lukashenko uses this definition for the relationship between the state and church. Due to the inequality between the weak church, which does not have sufficient autonomy and possibilities, and the state that is striving to expand its power to the whole social life of Belarus and control over civic society (Vasilevich 2015: 117), the church exists in the Belarusian regime more like a "bird in a golden cage". The church is given preferences by the state, but it does not have the opportunity to operate as a lobbyist structure and truly influence Belarusian politics; thus, its opinion is heard only when it is in agreement with that of the state (Mitrochin 2004: 503).

Lukashenko has the same approach to clergy and the exarch as they do to state officials, which is also confirmed by his statements, in which the metropolitan is considered to be a "state official" (President of the Republic of Belarus 2020a) and clergy "[...] an important cornerstone in the foundations of Belarusian statehood" (President of the Republic of Belarus 2021). In my opinion, relations between the church and state in Belarus are best evidenced in Lukashenko's speech, in which he claimed that

it is very fashionable to say that the church is divided from the state. From the first days of my presidency I have said and tirelessly repeated: the church, primarily the Orthodox Church, is the primary bond of our state, especially now, as the world has gone mad and lost its spirituality. How is it possible to divide the church from the state, and thus leave it outside the state? It is impossible. It is a pillar, one of the primary pillars of the state; an ideological one, if you will (President of the Republic of Belarus 2020a).

In 2003, a cooperation agreement was signed between the Belarusian state and BOC in which, among other things, the state acknowledged BOC as an important social institution whose experience, cultural heritage and spiritual potential have significantly influenced the formation of the spiritual, cultural and national traditions of the Belarusian people. The church agreed that its relationship to the state was based upon respect for the state as an institution that ensures social order, protects national interests, ethics, and protects the spiritual and cultural values of the nation (Exarchate 2003). This agreement became the basis for the signing of bilateral agreements between BOC and the Office for Criminal Law Enforcement, border troops, the National State Broadcasting Company of the Belarus Republic and the Department for Civil Aviation. In addition to this, various programs of cooperation between BOC and some ministries were created, and also with the National Academy of Sciences. A document on cooperation with the Committee on the Problems of the Consequences of the Catastrophe at the Chernobyl NPP was created and adopted due to the opinion that the "development of regions contaminated by radionuclides on the path to sustainable development is impossible without a positive change to mankind's worldview, culture and system of opinions, values, and priorities" (Exarchate 2006).

Despite the existence of the cooperation agreements, the Law of the Republic of Belarus "On freedom of conscience and religious organizations" complicates equal co-operation. Regardless of the fact that the state guarantees that it will not interfere in the activity of religious organizations (this sentence we can also find in the cooperation agreement was signed between the

\footnotetext{
${ }^{2}$ The first Belarusian exarch is one of 11 individuals to have been given the highest Belarusian award - Hero of Belarus (the same award has been given to individuals such as the director of BelaAZ, representatives of various agricultural companies, etc.).
} 
Belarusian state and BOC), it can do so if the religious organization carries out activity that is in contradiction with the laws of Belarus or if it is focused against the sovereignty of Belarus, its constitutional system and civil agreement, or if it is linked to the violation of its citizens' rights and freedoms and prevents citizens from fulfilling their state, social and family responsibilities or harms health and morals. Within the Belarusian system, however, this can be seen as any such activity that is in contradiction with Lukashenko's opinions.

Since BOC does not pose a threat to the regime, but rather strengthens its position, Lukashenko's regime allows BOC to be active in the media through the programs "Voskresnaya propovyed" on ONT TV channel and "Isnasć" on Belarus 1. In addition, services during the most important church holidays are broadcast live and the president himself, although an "Orthodox atheist", is present in the churches.

Since 2010, BOC has been allowed to enter into the education system in the form of the "basics of Orthodox culture" elective subject. It should be mentioned that a similar subject also exists in Russia, but Belarus has its own schoolbooks on the subject and a greater time allotment for its instruction. The state has also supported the building and reconstruction of new cathedrals and monasteries, financed the reconstruction of temples, helped train staff in the development of religious education, and always tried to be forthcoming to BOC's requests for aid (e.g. President of the Republic of Belarus 2020b).

At the same time, Lukashenko can give advice to the church. In 2013, for example, he said that the church should be reformed because their sermons were too long (President of the Republic of Belarus 2013). In 2015 he expressed his surprise over the fact that high-ranking church representatives do not have children and claimed they should have them (Interfax 2015). In addition, he also expressed his inability to understand why every village does not have its own clergy member. He also said that if the church is not capable of financing such clergy members, the state could do it instead (President of the Republic of Belarus 2020a).

In return for state aid and within their powers in the system, church representatives help to legitimize Lukashenko's activity and his regime. They call Lukashenko the "leader of the nation" and repeatedly commend him for the development that Belarus has undergone, and in their minds people in Belarus have all their life's needs covered thanks to this (e.g. BOC 2015, 2016).

\section{The Belarusian Orthodox Church and protests in 2010 and 2020}

Several examples can be found in the history of Belarus when the leadership of the BOC disagreed with Lukashenko's politics. One example of this were the presidential elections in 2010. After these elections, which according to opposition parties and the OSCE were neither competitive nor fair and were most probably falsified, extensive demonstrations were held and subsequently violently dispersed. Hundreds of people were arrested including several of the opposition candidates (OSCE 2010). Before the elections, the church did not support or have the opportunity to support Belarus's op-position parties; however, when violent suppression of the demonstration took place, BOC's leadership was hesitant to congratulate Lukashenko and thus confirm the legit-imacy of the election results, which was not common practice for BOC. In addition, the official journal of the Minsk eparchy published letters from parishioners calling for the church's leadership to condemn the position of the state authorities (Vasilevich 2013: 90).

Contrary to BOC, Russian patriarch Kirill congratulated Lukashenko on his election. In his letter, he stated that the results of the election showed the degree of trust that the people have in Lukashenko and the content of his letter generally meant that he saw the elections as being de facto legitimate (ROC 2010a). However, this step by the patriarch elicited outrage among 
Orthodox activists, who wrote the patriarch an open letter; nonetheless, it failed to yield any results (Vasilevich 2013: 90).

The second example are the presidential elections in 2020, which Western states declared to be unfair, unfree and falsified while refusing to acknowledge their results (Courtney and Haltzel 2020). The falsification of elections elicited extensive protests, which were violently subdued. According to the OSCE, human rights were massively violated and torture was carried out as peaceful demonstrations were suppressed (OSCE 2020). While Western states called upon Lukashenko to refrain from using force and hold new elections, ROC and representatives of the Russian state congratulated Lukashenko on his being elected, thus acknowledging and legitimizing the results of the elections. In his congratulatory telegram, Patriarch Kirill wrote to Lukashenko:

[f] or many years, you have attempted to protect the national interests of your country, and you have cared for its social-economic development and the peaceful and prospering life of its citizens. It is also pleasing to note that you have always paid attention to issues of the spiritual and moral state of the people, proof of which can be seen in the fruitful interactions between the state authorities and the Belarusian exarchate (ROC 2020).

Initially, it seemed as if the situation from 2010 was repeating itself, as metropolitan Pavel followed Kirill in congratulating Lukashenko.

Your fellow citizens have put great hopes in you in the context of the protection of Belarus's sovereignty, the protection of national and cultural heritage, and the strengthening of social and economic stability. We believe that the further activity of the state system of the Belarusian Republic will take place with the participation of all healthy social powers based on the spiritual and moral values formed in the bosom of the Christian tradition (BOC 2020a).

On August 12, when the protests and repression of protestors were both gaining force, Pavel organized a press conference in which he repeated Lukashenko's opinion concerning the significant roles of Western states in the Belarusian protests (from the context, it is clear that the external powers that had an influence on Belarusian protests were seen by Pavel to be "dark forces and their servants") and called upon those who had come to Belarus to incite protests to return home and let the Belarusian people live and select their own desired path of development. Although he indirectly condemned the police forces for using violence, he said it was necessary for them to "measure their force and resources against those who today think there is a different path but do not know how to approach it properly" (BOC 2020b).

It is also clear from Pavel's following speeches, his public activity or calls by the Belarusian exarchate that the Belarusian Church acknowledges the results of the elections and is calling upon people for reconciliation. At the same time, however, he condemns the violence that was used against the protestors. For example, in metropolitan Pavel's speech from August 14, he called upon citizens not to create tension but to pray. He also asked the clergy not to express their opinions of the events and only urge people towards peace, as the state's leadership listens to the people (BOC 2020c). A prayer for the Belarusian people that they read during services in churches contained a call for giving "the gift of reconciliation and consideration" (BOC 2020d). On the other hand, in the same speech from August 14, Pavel repeatedly asked Lukashenko as president, guarantor of the constitution and commander in chief to stop the violence (BOC 2020c). The BOC provided aid to people who suffered injuries during the protests (BOC 2020e). The metropolitan himself even visited injured people in hospitals. In the context of this event, BOC's website claimed that the patients were people injured during the protests, but there were 
also random bystanders among the protestors. It also claimed that a number of the individuals with signs of being beaten or severely attacked were sent to the hospitals directly from a detention center, and that all had suffered significant physical and psychological harm (BOC 2020f). Later, a BOC spokesperson revealed that clergy members had been at the detention centers. However, BOC avoided giving heightened attention to this event, as it assumed that "too much attention could limit BOC's possibilities" (Mudrov 2020).

Although the church called upon its clergy members not to take part in the events and not to express their opinions on the matter, individual church representatives organized stations of the cross and individual protests. They participated in a flash mob against falsifications during the Presidential Elections (Faustova 2020). Archbishop Artemiy of Grodno supported antigovernment rallies, denounced the use of violence and the behavior of state representatives not only via official statements, but also from the ambon (Grodno eparchy 2020a; Grodno eparchy 2020b). Clergy member of the Gomel eparchy Vladimir Drobyshevsky was arrested and imprisoned for 25 days for his participation in a peaceful demonstration (Butkovich 2020).

Lukashenko, who claimed that the unemployed and people with a criminal past were taking part in the protests while casting doubt on the fact that they had been injured in a detention center (or even if they had been, in his opinion, they were drug addicts and other unreliable citizens) (e.g. President of the Republic of Belarus 2020c, 2020d, 2020e), was "surprised" by this position of the church. At a propresidential meeting on August 22, he recommended that the clergy come to their senses and refuse to support the opposition, as the state would not be willing to close a blind eye (President of the Republic of Belarus 2020f). Several days later, metropolitan Veniamin, a Belarusian partial to Lukashenko, was placed as the head of BOC. Metropolitan Pavel returned to Russia to the Kuban eparchy. The media and experts linked Pavel's return to Russia with Lukashenko's disagreement with Pavel's position during the protests (e.g. Kurayev, Naryshkin 2020; Faustova 2020).

During the first meeting with Veniamin, Lukashenko pointed out to the metropolitan that, over a five-year period, the shortcomings of the clergy would have to be remedied and also that "if even one single organization in Belarus, either public or private, focuses on destroying the state [according to Lukashenko, the Catholic Church was behaving in such a manner during the protests - author's note], it will clearly have to react" (President of the Republic of Belarus 2020a).

After a change of exarchs and Lukashenko's warning, church actors continued on in support of the opposition. They voiced their support for Igor Losik, who was arrested for political reasons (Mitskevich 2021), and denounced the security forces' destruction of a spontaneous memorial to commemorate murdered Minsk inhabitant Roman Bondarenko (Lepin 2020). This became the reason Sergei Lepin stepped down from his post as BOC's spokesperson (Belstat 2020). Archbishop Artemiy of Grodno was retired in June 2021 "for health reasons", but Artemiy himself directly links his resignation to his negative stance on the elections and subsequent events in Belarus (Prokof'yeva 2021).

\section{The Russian Orthodox Church, the Russian state and Belarus}

Lukashenko's election led to expectations in ROC concerning closer cooperation between Russia and Belarus, and therefore ROC confirmed the signing of an agreement to create the Union of Russia and Belarus. Patriarch Alexy II himself was present at the ceremony of the agreement's signing and gave his blessing to the steps taken by Russian and Belarusian leadership (Patriarch 1996). ROC's representatives can be said to have continued in their support of Russian and Belarusian leadership in questions of integration, despite the fact that the patriarch was not present for the signing of the agreement on the creation of a Union State of Russia and Belarus. 
According to the statements by ROC leadership in Moscow that are accessible on ROC's official website, it can generally be seen as inclined towards Lukashenko.

In sources (e.g. Lamoreaux, Mabe 2019), ROC is often considered to be a tool of the Kremlin's influence on other states; however, in my opinion, the situation is different in Belarus's case. On one hand, as was mentioned previously, this is due to the fact that the BOC's possibilities are limited in a regime in which the state fights against civic society and against actors that do not support the regime. On the other hand, Lukashenko has made it possible to view the Russian Church's exarchate as an exceptionally national church to which the majority of Belarusians belong (Budkin 2007: 31). This has happened due to the helpfulness of the Belarusian Church's role in legitimizing Lukashenko's policy. The Belarusian Church also plays a different and, in my opinion, rather important role that most experts neglect. In moments when ties worsen between Belarusian and Russian leadership, Lukashenko always recalls the fact that BOC is a part of ROC, which has certain power in the Russian system, and begins to take steps that are not acceptable for ROC. In my view, he tries to influence the opinion and decision making of Russian leadership via ROC. ${ }^{3}$

The first case in which Lukashenko clearly attempted to make use of ROC took place in 2002, when a cooling of ties between Russia and Belarus took place as a result of Lukashenko's disagreement with Russia's leadership concerning the development of the Union State (Vilgelm 2002). After failed negotiations with Putin, Lukashenko unex-pectedly proclaimed to the Belarusian public that he would like the Pope to visit Belarus in the nearest future. Although a relatively large number of Catholics lives in Belarus, such a visit to the whole canonical territory, especially Belarus and Ukraine, was unac-ceptable to ROC at the time (Mitrochin 2004: 503). Once ties between Russia and Belarus began to improve, the Belarusian president ceased to speak of the pope visiting Belarus; on the contrary, he signed the special cooperation agreement discussed above with BOC (Mitrochin 2004: 503).

During heated conflicts in 2006-2007, Lukashenko did not make use of the church factor. However, he returned to it in 2009-2010, when relationships between Russia and Belarus were experiencing significant tension and a number of conflicts over oil, gas, food supplies, tractors, loans, and the acknowledgment of Abkhazia and South Ossetia. Although Russian patriarch Kirill claimed during his visit to Belarus in 2009 during a meeting with President Lukashenko that the church was always prepared to be a me-diator between Belarusian and Russian leadership (ROC 2009) or they discussed issues of Russian-Belarusian ties and how Kirill had come to "understand much about relationships between Belarus and Russia" (President of the Republic of Belarus 2009a), but the situation with the Vatican occurred once again. The Belarusian president invited the Pope to Belarus (President of the Republic of Belarus 2009b). Later, in 2010, Lukashenko flew to Istanbul where, according to sources, he unofficially negotiated the issue of possibly providing independence to BOC with the Constantinopolitan patriarch. Experts view this step as Lukashenko's attempt to exert pressure on Russia (e.g. Credo.ru 2010; Mal'tsev 2015).

At the end of 2013 when the crisis in Ukraine was gaining momentum, metropolitan Pavel, who at the time headed the Ryazan eparchy, was nominated to the head of the Belarusian Church. The official argument for his nomination was the request made by the Belarusian metropolitan Philaret, who decided to resign from his post due to his deteriorating state of health ${ }^{4}$ (Perchin 2015). Pavel was surprised by being nominated (Kozlik 2013), and it can be assumed that ROC also took this step to place a person that would be loyal to ROC's leadership in Moscow at the

\footnotetext{
${ }^{3}$ Lukashenko himself spoke of the fact that various meetings with the patriarch in Russia are an additional opportunity for further negotiations with Russian policymakers (e.g. President of the Republic of Belarus 2017).

${ }^{4}$ Philaret had written this request already in 2009. At the time, however, the request was denied (Perchin 2015).
} 
head of the Belarusian exarchate, which meant he would not make efforts towards the possible autonomy of the Belarusian Church.

[I] wish you God's help in [...] preserving the unity of our church, in preserving the unity of historical Russia, which - despite many weaknesses and devastations, including the 20th century - remains a great spiritual and civilizational power of the modern world (ROC 2014)

- said patriarch Kirill in his welcoming speech to metropolitan Pavel. In the first months after Pavel's nomination, ties between Belarusian leadership and Pavel showed that this nomination was probably not negotiated with Lukashenko (Perchin 2015). Although Pavel lived in the residence of the Belarusian president (Mal'tsev 2015), Belarusian society abounded with rumors that Lukashenko was dissatisfied with Kirill's steps. In addition, Pavel did not speak Belarusian, which is the widespread language of religious services, and was not a citizen of Belarus and thus according to Belarusian laws could not head BOC (RFE/RL 2014). His opinions and previous speeches also evoked questions among the Belarusian opposition public. For example, in 2011, he said in response to external pressure that

if they drive our nation [the population of Russian - author's note] into a corner, we shall be left with no other option than to open the tap of Chernobyl. In this case, everyone would suffer: Americans, Europeans, and the rich (Lenta.ru 2014).

This speech was spread in Belarusian non-state media and a letter even appeared in which the Belarusian opposition criticized the metropolitan and linked his operations to Russia's efforts to increase its influence (e.g. RFE/RL 2014).

Dissatisfied by the events in Ukraine in 2014, Lukashenko at least began to speak with new intensity about greater autonomy for the Belarusian Church. Even members of the Belarusian clergy wrote Pavel a letter with a request to ask patriarch Kirill for greater autonomy or self-rule according to the model of churches in Latvia, Moldova and Estonia. At the end of 2014, Pavel, who had been considered the "extended arm of the Kremlin" announced he would be requesting Moscow's leadership to grant the Belarusian Church greater autonomy (Belta 2014). This was certainly not in agreement with Kirill's position, who on the contrary was striving not to support autonomy and de facto bring all ROC's "branches" under his direct control. Therefore, Pavel's step was not greeted with understanding in Moscow. After some time, however, Pavel declared that the issue of BOC's greater autonomy would not be reopened in the next 25 to 50 years (Mal'tsev 2015).

A new cooling of ties between Russia and Belarus over the course of 2016 led Lukashenko once again to speak of his desire to be the mediator between ROC and the Vatican and his repeated willingness to invite the Pope on a visit to the Vatican (Mal'tsev 2016) (despite outwardly improving relations between ROC and the Vatican, such a step is still unacceptable today).

However, it is not possible to claim that the BOC's position in Belarus and its evident exploitation by Belarusian leadership for its own purposes could have significantly af-fected relations between Belarusian leadership and ROC leadership in Moscow, as the patriarch continues to express his support for Lukashenko and his regime in his speeches (e.g. ROC 2010b, 2011).

After elections in 2020, when Russia was one of the few states to support the reelection of Lukashenko, Lukashenko not only spoke of the fact that creating an independent Belarusian Church in Belarus was impossible, but also presented proposals to establish an autocephalous Church as primarily as the hostile activity of "opponents to Belarusian statehood" (President of the Republic of Belarus 2021). Given that it is the opposition (or everyone who do not agree with Lukashenko's politics) that is presented in Lukashenko's speeches as "opponents of Belarusian 
statehood" this can also be seen as a distinctive signal for Moscow - "Only I can ensure that BOC will be a part of ROC".

The issue of the independence of the Belarusian Church is also used as another opportunity to criticize the West. Just like Russian officials and intellectuals who viewed these events as attempts by the West to fight Orthodoxy in Russia during the conflicts linked to ROC in 2012 (Naxera 2018: 131-134), Lukashenko too regards the West's actions towards Belarus after August 2020 as an attempt to break Belarusian Orthodoxy, which is "fundamental to the existence of the Belarusian nation" (President of the Republic of Belarus 2021). ${ }^{5}$ This means that the hostile West is trying to destroy the "century-old fundamentals" in Belarus (President of the Republic of Belarus 2021). Contrary to Russia, these fundaments do not manifest themselves in traditional values, but primarily in the unity of the nation that the Belarusian Church should strive towards (President of the Republic of Belarus 2021). In the Belarusian context, however, this means that church representatives should submit to existing secular power and should not express their stances or wishes to change the political situation.

The Belarusian president not only spoke of the fact that creating an independent church in Belarus was impossible, but he also began to see the arrival of the Pope as unsuitable. He backed his arguments by citing the problems ROC has with the Catholic Church and promised that the Pope would not come to Belarus until ROC agrees to him doing so (President of the Republic of Belarus 2020a).

\section{Conclusion}

In this presented text, the author has dealt with the role that the Belarusian Orthodox Church plays in the contemporary Belarusian regime. Research has shown that the present BOC does not belong to either of the aforementioned models of ties between a church and an undemocratic state. On one hand, favorable conditions exist for the development of BOC. For example, state institutions are signing agreements of cooperation and financing the construction of new churches. In addition, the church is allowed to enter into the education system or the media. On the other hand, although the state declares the de facto independence of BOC, it can interfere in its personnel policy when church representatives carry out activity that the state perceives as a threat to the regime. This leads church organizations in such systems to become significantly weakened within this "cooperation with the state", even though they have an influence on society and thus a legitimizing potential. This results in the church's strong dependence on the state and limitations to it as an actor in civic society within the Belarusian regime.

In my opinion, this is one of the reasons why it is difficult to speak of BOC as being a tool of the Kremlin's influence. The next reason is the fact that Lukashenko has allowed the exarchate of the Russian Church to be perceived as an exceptional national church that the majority of Belarusians belong to. This text has shown that, in addition to holding a legitimizing function within the Belarusian regime, the Belarusian Church also plays another and, in my opinion, highly important role. It is used by the state as a tool utilized by Lukashenko to influence the opinion and decisions of Russian leadership. It means, that in the present conditions, we can claim that Lukashenko does not actually need an independent church - BOC is completely subordinate to him and, in addition, it can be used as another tool to exert pressure on Moscow.

\footnotetext{
${ }^{5}$ Generally speaking, Lukashenko's rhetoric after August 2020 concerning the West's activity towards Belarus has been harsher than the rhetoric of official Russian representatives and is more reminiscent of the rhetoric of influential Russian intellectuals (e.g. Naxera 2017).
} 


\section{References}

Åberg, M., T. Denk. 2017. "Democratization and Secularization: Towards a Process-Oriented Model." Politics, Religion ES Ideology 18 (2): 175-197, https://doi.org/10.1080/21567689.2017.1327851.

Avanesova, M., V. Naxera. 2018. "Za ochranu křestanstvį́: postoje ruské pravoslavné církve vůči Západu a její místo v zahraniční politice Ruské federace." Mezinárodní vztahy / Czech Journal of International Relations 53 (2): 20-42, https://doi.org/10.32422/mv.1554.

Belstat. 2020. "Press-sekretar' BPTS Sergey Lepin uvolilsya posle kritiki Lukashenko." [online] Belstat [retrieved 4. 5. 2021]. https://belsat.eu/ru/news/press-sekretar-bpts-sergej-lepin-uvolilsya-posle-kritikilukashenko/.

Belta. 2014. "Dukhovenstvo poprosilo mitropolita Pavla khodataystvovat' o predostavlenii BPTS samoupravleniya po obraztsu tserkvey Latvii, Moldovy i Estonii." [online] Belta [retrieved 4. 5. 2021]. https://www.belta.by/society/view/duhovenstvo-poprosilo-mitropolita-pavla-hodatajstvovat-opredostavlenii-bpts-samoupravlenija-po-obraztsu-61735-2014.

Bezborodov, M. 2010. "Mezhdunarodnaya deyatel'nost' Russkoy Pravoslavnoy Tserkvi: vneshnepoliticheskiye pozitsii i sotrudnichestvo s gosudarstvom." Socium $i$ vlast' 3: 84-89.

BOC. 2015. "Mitropolit Pavel pozdravil Aleksandra Lukashenko s izbraniyem na post Glavy belorusskogo gosudarstva." [online] BOC [retrieved 4. 5. 2021]. http://church.by/news/mitropolit-pavel-pozdravilaleksandra-lukashenko-s-izbraniem-na-post-glavy-belorusskogo-gosudarstva.

BOC. 2016. "Mitropolit Minskiy i Zaslavskiy Pavel pozdravil Prezidenta Respubliki Belarus' Aleksandra Lukashenko s Dnem Nezavisimosti." [online] BOC [retrieved 4. 5. 2021]. http://church.by/news/mitropolit-minskij-i-zaslavskij-pavel-pozdravil-prezidenta-respubliki-belarusaleksandra-lukashenko-s-dnem-nezavisimosti.

BOC. 2020a. "Patriarshiy Ekzarkh Vseya Belarusi pozdravil Aleksandra Lukashenko s izbraniyem na post Prezidenta Respubliki Belarus." [online] BOC [retrieved 4. 5. 2021]. http://church.by/pub/news/patriarshij-ekzarh-vseja-belarusi-pozdravil-aleksandra-lukashenko-sizbraniem-na-post-prezidenta-respubliki-belarus.

BOC. 2020b. "Mitropolit Pavel: davayte vmeste ostanovim vrazhdu i nenavist." [online] BOC [retrieved 4. 5. 2021]. http://church.by/pub/news/mitropolit-pavel-davajte-vmeste-ostanovim-vrazhdu-inenavist-video.

BOC. 2020c. "Patriarshiy Ekzarkh: obrashchayus' k Glave gosudarstva i proshu." [online] BOC [retrieved 4. 5. 2021]. http://church.by/pub/news/patriarshij-ekzarh-obrashajus-k-glave-gosudarstva-iproshu-sdelat-vse-vozmozhnoe-chtoby-ostanovit-nasilie.

BOC. 2020d. "Vo vsekh khramakh Belorusskoy Pravoslavnoy Tserkvi molyatsya o darovanii mira narodu Belarusi." [online] BOC [retrieved 4. 5. 2021]. http://church.by/news/vo-vseh-hramah-belorusskojpravoslavnoj-cerkvi-budut-molitsja-o-darovanii-mira-narodu-belarusi.

BOC. 2020e. "Belorusskaya Pravoslavnaya Tserkov' prodolzhayet okazyvat' pomoshch' postradavshim v khode aktsiy protesta." [online] BOC [retrieved 4. 5. 2021]. http://church.by/news/belorusskajapravoslavnaja-cerkov-prodolzhaet-okazyvat-pomosh-postradavshim-v-hode-akcij-protesta.

BOC. 2020f. "Patriarshiy Ekzarkh navestil lyudey, postradavshikh v khode protestnykh aktsiy." [online] $B O C$ [retrieved 4. 5. 2021]. http://church.by/news/patriarshij-ekzarh-navestil-ljudej-postradavshih-vhode-protestnyh-akcij.

Budkin, V. 2007. "Gosudarstvo i religiya na postsovetskom prostranstve." Kavkaz i globalizacija 5 (1): $25-47$.

Butkovich, N. 2020. "Svyashchenniku iz Gomelya Vladimiru Drobyshevskomu zapretili nosit' svyashchennicheskiye odezhdy i naperstnyy krest." [online] Komsomolskaya Pravda, 30.12.2020 [retrieved 4. 5. 2021]. https://www.kp.by/online/news/4138149/.

Courtney, W., M. Haltzel. 2020. "The West's Role in Belarus." [online] RAND cooperation, 18.8. 2020 [retrieved 4. 5. 2021]. https://www.rand.org/blog/2020/08/the-wests-role-in-belarus.html.

Credo.ru. 2010. "Vopros avtokefalii Belorusskoy Tserkvi obsuzhdal Aleksandr Lukashenko s Patriarkhom Varfolomeyem, utverzhdayut istochniki v Belorusskom ekzarkhate RPTS MP." [online] Credo.ru [retrieved 4. 5. 2021]. https://credo.press/115531/.

Curanović, A. 2012. The Religious Factor in Russia's Foreign Policy. London: Routledge.

Exarchate. 2003. "Soglasheniye o sotrudnichestve mezhdu Respublikoy Belarus' i Belorusskoy Pravoslavnoy Tserkov'yu." [online] Exarchate [retrieved 4. 5. 2021]. http://exarchate.by/resource/Dir0009/Dir0015/. 
Exarchate. 2006. "Programma sotrudnichestva Komiteta po problemam posledstviy katastrofy na Chernobyl'skoy AES pri Sovete Ministrov Respubliki Belarus' i Belorusskoy Pravoslavnoy Tserkvi po voprosam preodoleniya posledstviy katastrofy na Chernobyl'skoy AES." [online] Exarchate [retrieved 4. 5. 2021]. http://exarchate.by/resource/Dir0009/Dir0015/Dir0442/Page0485.html.

Faustova, M. (2020). "Sinod RPTS otozval mitropolita-"varyaga"iz Belorussii." [online] Nezavisimaya Gazeta, 25.8. 2020 [retrieved 4. 5. 2021]. https://www.ng.ru/faith/2020-08-25/1_7946_religion.html.

Grodno eparchy. 2020a. "Obrashcheniye arkhiyepiskopa Grodnenskogo i Volkovysskogo Artemiya k kliru i pastve Grodnenskoy yeparkhii." [online] Grodno eparchy [retrieved 4. 5. 2021]. https://orthos.org/eparhiya/bishop/speech/2020/08/14/obrashchenie-arhiepiskopa-grodnenskogovolkovysskogo-artemiya-k.

Grodno eparchy. 2020b. "Slovo arkhiyepiskopa Artemiya o nasilii v Belarusi." [online] Grodno eparchy [retrieved 4. 5. 2021]. https://orthos.org/media/video/2020/08/16/slovo-arhiepiskopa-artemiya-o-nasiliibelarusi.

Interfax. 2015. "Lukashenko znayet svyashchennikov, kotoryye "kosyachat", narushaya zapret na rozhdeniye detey, no ne osuzhdayet ikh." [online] Interfax [retrieved 4. 5. 2021]. https://interfax.by/news/obshchestvo/kultura/1182934/.

Koesel, K. 2017. "Religion and the Regime: Cooperation and Conflict in Contemporary Russia and China." World Politics 69 (4): 676-712, https://doi.org/10.1017/S004388711700017X.

Kozlik, I. 2013. "Novyy mitropolit Minskiy i Slutskiy Pavel: 'Po sravneniyu s Vladykoy Filaretom ya neopytnyy chelovek, negramotnyy i molodoy"'. [online] Komsomolskaya Pravda, 30.12.2013 [retrieved 4. 5. 2021]. https://www.kp.by/daily/26177.4/3066020/.

Kurayev, A., A. Naryshkin. 2020. "Personal'no Vash." [online] Echo Moskvy, 26.8.2020 [retrieved 4. 5. 2021]. https://echo.msk.ru/programs/personalnovash/2698527-echo/.

Lamoreaux, J. W., M. Mabe. 2019. "The Kremlin's strategy vis-à-vis the Baltic States: a role for Orthodoxy." International Journal for the Study of the Christian Church 19 (4): 286-301, https://doi.org/10.1080/1474225X.2019.1678374.

Lenta.ru. 2014. "Podstrekateley ukrainskogo krizisa pripugnuli Strashnym sudom." [online] Lenta.ru [retrieved 4. 5. 2021]. https://lenta.ru/news/2014/04/21/pavel/.

Lepin, S. 2020. "Post on Facebook." [online] Facebook, 15. 10.2020. https://www.facebook.com/sergy.lepin/posts/3694576197261785.

Letsie, T. 2015. "The role of Christian churches in political conflict in Lesotho." African Security Review 24 (1): 75-88, https://doi.org/10.1080/10246029.2014.993669.

Leustean, L. N. 2018. "The politics of Orthodox churches in the European Union." International Journal for the Study of the Christian Church 18 (2-3): 146-157, https://doi.org/10.1080/1474225X.2018.1504598.

Lomagin, N. 2012. "Interest groups in Russian foreign policy: The invisible hand of the Russian Orthodox Church." International Politics 49 (4): 498-516, https://doi.org/10.1057/ip.2012.13.

Mal'tsev, V. 2015. "Bat'ka ne poluchit suverennuyu Tserkov'." [online] Nezavisimaya Gazeta, 21.1.2015 [retrieved 4. 5. 2021]. https://www.ng.ru/ng_religii/2015-01-21/4_lukashenko.html.

Mal'tsev, V. 2016. "Minsk khochet byt' mostom mezhdu Moskvoy i Vatikanom." [online] Nezavisimaya Gazeta, 16.3. 2016 [retrieved 4. 5. 2021]. http://www.ng.ru/ng_religii/2016-03-16/2_minsk.html.

McCallum, F. 2012. "Religious Institutions and Authoritarian States: church-state relations in the Middle East." Third World Quarterly 33 (1): 109-124, https://doi.org/10.1080/01436597.2012.627238.

McGraw, B. 2014. "Religious parties and the problem of democratic political legitimacy." Critical Review of International Social and Political Philosophy 17 (3): 289-313, https://doi.org/10.1080/13698230.2014.886383.

Mitrofanova, A. 2007. "Imeet li Russkaya Pravoslavnaya Cerkov' ob"edinyayushhee znachenie dlya sootechestvennikov v stranax SNG i Baltii." [online] IA Centr, 21.2. 2007 [retrieved 6. 2. 2017]. http://iacentr.ru/archive/comments6a70.html?id $=387$.

Mitrochin, N. 2004. Russkaya pravoslavnaya tserkov': sovremennyye sostoyaniye $i$ aktual'ne problemy. Moskva: Novoye literaturnoye obozreniye.

Mitskevich, P. 2021. "Dva svyashchennika BPTS podali v SK khodataystva o lichnom poruchitel'stve za golodayushchego Igorya Losika." [online] Komsomolskaya Pravda [retrieved 5. 7. 2021]. https://www.kp.by/online/news/4157647/.

Mudrov, S. 2020. "Nashi svyashchenniki byli u izolyatorov na Okrestina'. Ob otnoshenii Belorusskoy Pravoslavnoy Tserkvi k protestam." [online] Pravmir, 6. 9. 2020 [retrieved 4. 5. 2021]. 
https://www.pravmir.ru/nashi-svyashhenniki-byli-u-izolyatorov-na-okrestina-ob-otnosheniibelorusskoj-pravoslavnoj-czerkvi-k-protestam/.

Naxera, V. 2017. "Vztah Ruska k Západu a státům postsovětské Evropy v díle Dugina, Solženicyna a Naročnické." Mezinárodní vztahy / Czech Journal of International Relations 52 (3): 90-111.

Naxera, V. 2018. "The West, Globalisation and Pussy Riot: Portrayals of Russia and Eurasia's enemies in the work of Aleksandr G. Dugin." Central European Journal of International and Security Studies 12 (1): 119-141.

OSCE. 2010. "Promezhutochnyy otchet no. 1." [online] OSCE [retrieved 4. 5. 2021]. https://www.osce.org/files/f/documents/e/3/73961.pdf.

OSCE. 2020. "Belarus must uphold international obligations and respect fundamental freedoms in wake of disputed election, OSCE PA President says." [online] OSCE [retrieved 4. 5. 2021]. https://www.osce.org/parliamentary-assembly/459997.

Patriarch. 1996. "Rech' v svyazi s podpisaniyem Rossiysko-Belorusskogo dogovora, 2 aprelya 1996 goda." [online] Patriarch [retrieved 4. 5. 2021], http://patriarh-i-narod.ru/slovo-patriarha/tserkov-iobshchestvenno-politicheskaya-zhizn/2032-rech-v-svyazi-s-podpisaniem-2-aprelya-1996-goda.

Perchin, L. 2015. "Nedolgiy srok belorusskogo vladyki." [online] NG Religiya, 21. 10. 2015 [retrieved 4. 5. 2021]. http://www.ng.ru/ng_religii/2015-10-21/4_belorussia.html.

Philpott, D. 2004. "Christianity and Democracy: The Catholic Wave." Journal of Democracy 15 (2): 32-46, https://doi.org/10.1353/jod.2004.0034.

Philpott, D. 2007. "Explaining the Political Ambivalence of Religion." The American Political Science Review 101 (3): 505-525, https://doi.org/10.1017/S0003055407070372.

President of the Republic of Belarus. 2009a. "Vstrecha s Patriarkhom Moskovskim i vseya Rusi Kirillom." [online] President of the Republic of Belarus [retrieved 4. 5. 2021]. https://president.gov.by/ru/events/aleksandr-lukashenko-vstretilsja-s-patriarxom-moskovskim-ivseja-rusi-kirillom-2942.

President of the Republic of Belarus. 2009b. "Vizit v Gosudarstvo Vatikan, Respubliku Italiyu i Suverennyy Mal'tiyskiy orden." [online] President of the Republic of Belarus [retrieved 4. 5. 2021]. https://president.gov.by/ru/events/aleksandr-lukashenko-sovershil-vizit-v-italjjanskujurespubliku-i-gosudarstvo-vatikan-2935.

President of the Republic of Belarus. 2013. "Oznakomleniye s khodom stroitel'stva akvaparka v Minske." [online] President of the Republic of Belarus [retrieved 4. 5. 2021]. https://president.gov.by/ru/events/aleksandr-lukashenko-oznakomilsja-s-xodom-stroitelstvaakvaparka-v-minske-6601.

President of the Republic of Belarus. 2017. "Vstrecha s predstavitelyami obshchestvennosti, belorusskikh i zarubezhnykh SMI 'Bol'shoy razgovor s Prezidentom'”. [online] President of the Republic of Belarus [retrieved 4. 5. 2021]. https://president.gov.by/ru/events/vstrecha-s-predstaviteljami-obschestvennostibelorusskix-i-zarubezhnyx-smi-15509\#block-after-media-scroll.

President of the Republic of Belarus. 2020a. "Vstrecha s mitropolitom Minskim i Zaslavskim Veniaminom, Patriarshim ekzarkhom vseya Belarusi." [online] President of the Republic of Belarus [retrieved 4. 5. 2021]. https://president.gov.by/ru/events/vstrecha-s-mitropolitom-minskim-i-zaslavskimveniaminom-patriarshim-ekzarhom-vseya-belarusi.

President of the Republic of Belarus. 2020b. "Poseshcheniye khrama v chest' svyatogo proroka Ioanna Predtechi." [online] President of the Republic of Belarus [retrieved 4. 5. 2021]. https://president.gov.by/ru/events/poseshchenie-hrama-v-chest-svyatogo-proroka-ioanna-predtechi.

President of the Republic of Belarus. 2020c. "Vstrecha s predsedatelem Ispolnitel'nogo komiteta - ispolnitel'nym sekretarem SNG Sergeyem Lebedevym." [online] President of the Republic of Belarus [retrieved 4. 5. 2021]. https://president.gov.by/ru/events/vstrecha-s-predsedatelem-ispolnitelnogokomiteta-ispolnitelnym-sekretarem-sng-sergeem-lebedevym.

President of the Republic of Belarus. 2020d. "Vystupleniye na zhenskom forume 'Za Belarus'". [online] President of the Republic of Belarus [retrieved 4. 5. 2021]. https://president.gov.by/ru/events/vystupleniena-zhenskom-forume-za-belarus.

President of the Republic of Belarus. 2020e. "Interv'yu predstavitelyam vedushchikh rossiyskikh SMI." [online] President of the Republic of Belarus [retrieved 4. 5. 2021]. https://president.gov.by/ru/events/intervyu-predstavitelyam-vedushchih-rossiyskih-smi. 
President of the Republic of Belarus. 2020f. "Uchastiye v mitinge v Grodno." [online] President of the Republic of Belarus [retrieved 4. 5. 2021]. https://president.gov.by/ru/events/uchastie-v-mitinge-v-grodno.

President of the Republic of Belarus. 2021. "Poseshcheniye Svyato-Uspenskogo Zhirovichskogo stavropigial'nogo muzhskogo monastyrya." [online] President of the Republic of Belarus [retrieved 20. 7. 2021]. https://president.gov.by/ru/events/poseshchenie-svyato-uspenskogo-zhirovichskogo-stavropigialnogomuzhskogo-monastyrya.

Prokof'yeva, Y. 2021. "My prevratilis' v tserkov' perioda zastoya'. Arkhiyepiskop Artemiy - o sluzhenii v RPTS." [online] Radio Svoboda, 13.6.2021 [retrieved 20. 7. 2021]. https://www.svoboda.org/a/myprevratilisj-v-tserkovj-perioda-zastoya-arhiepiskop-artemiy-o-sluzhenii-v-rpts/31305170.html.

RFE/RL. 2014. "Viadomyja bielarusy asudzili pryznačeńnie mitrapalita Paǔla." [online] $R F E / R L$ [retrieved 20. 7. 2021]. https://www.svaboda.org/a/25248310.html.

ROC. 2009. "Sostoyalas' vstrecha Svyateyshego Patriarkha Kirilla s Prezidentom Respubliki Belarus' A. G. Lukashenko." [online] ROC [retrieved 4. 5. 2021]. http://www.patriarchia.ru/db/print/749787.html.

ROC. 2010a. "Patriarsheye pozdravleniye A. G. Lukashenko s pereizbraniyem na post Prezidenta Respubliki Belarus." [online] ROC [retrieved 4. 5. 2021]. http://www.patriarchia.ru/db/text/1347158.html.

ROC. 2010b. "Patriarsheye pozdravleniye Prezidentu Respubliki Belarus' A. G. Lukashenko s dnem rozhdeniya." [online] ROC [retrieved 4. 5. 2021]. http://www.patriarchia.ru/db/text/1261582.html.

ROC. 2011. "Poslaniye Svyateyshego Patriarkha Kirilla Prezidentu Belorussii A. G. Lukashenko." [online] ROC [retrieved 4. 5. 2021]. http://www.patriarchia.ru/db/text/1401210.html.

ROC. 2014. "Slovo Svyateyshego Patriarkha Kirilla v den' pamyati svyatitelya Petra, vseya Rossii chudotvortsa, v Uspenskom sobore Moskovskogo Kremlya." [online] ROC [retrieved 4. 5. 2021]. http://www.patriarchia.ru/db/text/3493201.html.

ROC. 2020. "Pozdravleniye Svyateyshego Patriarkha Kirilla A. G. Lukashenko s pobedoy na vyborakh Prezidenta Respubliki Belarus." [online] ROC [retrieved 4. 5. 2021]. http://www.patriarchia.ru/db/text/5675082.html.

Ryabych, J. 2004. "Politicheskiye partii Rossii i Russkaya Pravoslavnaya Tserkov'" Politeia 1: 124-148.

Sekerák, M. 2014. "Dávid a Goliáš: Spolu alebo proti sebe? Bilaterálne vztahy Svätej stolice a USA v kontexte medzinárodnej politiky." Acta Fakulty filozofické Západočeské univerzity v Plzni / West Bohemian Review of Social Sciences \& Humanities 6 (3): 52-84.

Serapião, L. B. 2004. "The Catholic Church and Conflict Resolution in Mozambique's Post-Colonial Conflict, 1977-1992." Journal of Church and State 46 (2): 365-387.

Shramko, A. 2014. "Avtokefaliya, avtonomiya, samoupravleniye." [online] Carkva, 23.12.2014 [retrieved 4. 5. 2021]. https://churchby.info/bel/978.

Schwörer, J., X. Romero-Vidal. 2020. "Radical right populism and religion: mapping parties' religious communication in Western Europe." Religion, State and Society 48 (1): 4-21, https://doi.org/10.1080/09637494.2019.1704611.

The Republic of Belarus. 2002. "Law of the Republic of Belarus "On freedom of conscience and religious organizations"." [online] UNESCO [retrieved 4. 5. 2021]. http:// www.unesco.org/education/edurights/media/docs/190938c389b7eba4c493f030e2e60e0b1e1362bc.pdf.

Urban, D. 2019. "Tsennosti naseleniya Belarusi." [online] Issledovatel'skiy tsentr IPM, May 2019 [retrieved 4. 5. 2021]. http://www.research.by/webroot/delivery/files/SR_19_01.pdf.

Vasilevich, N. 2013. "Belorusskaya pravoslavnaya tserkov'v teni gosudarstva." Pro et Contra 3: 80-96.

Vasilevich, N. 2015. "Unequal by default: Church and state in Belarus in the period of consolidated authoritarianism." Pp 67-96 in V. Bulhakau, A. Lastouski (eds.). Civil Society in Belarus 2000-2015. Collection of Texts. Warsaw: East European Democratic Centre.

Vilgelm, S. 2002. "Protivorechiya mezhdu Rossiyey i Belorussiyey." [online] DW, 23. 8.2002 [retrieved 4. 5. 2021]. http://p.dw.com/p/2aBf.

Vojtovich, N. 2003. "Belarus' stala forpostom pravoslaviya." [online] DW, 2.3. 2003 [retrieved 4. 5. 2021]. https://p.dw.com/p/369y.

Wilkins-Laflamme, S. 2016. "Protestant and Catholic Distinctions in Secularization." Journal of Contemporary Religion 31 (2): 165-180, https://doi.org/10.1080/13537903.2016.1152660. 


\section{About author}

Maria Avanesova graduated from the International Relations program of the Department of Politics and International Relations of the University of West Bohemia in Pilsen. Currently she is a PhD student at the same department. Her main field of research is Russian foreign policy with special attention to religious and cultural factors. ORCID: http://orcid.org/0000-0003-2793-5570. 